that prostaglandin $\mathrm{E}_{2}$ is more effective in inducing labour must be considered with caution, for though the patients were selected at random the groups were not identically matched.

The differences found in these studies may be partly explained by essential differences in the plan of each investigation and the exact protocol undertaken. Beazley and Gillespie (1971) started the infusion of prostaglandin $E_{2}$ at $0.21 \mu \mathrm{g} / \mathrm{min}$ and oxytocin at $2 \cdot 1 \mathrm{mU} / \mathrm{min}$. These rates were doubled every hour until contractions were effective and then usually maintained at a fixed rate. In addition some patients' membranes were ruptured artificially when labour was established. Our approach was basically different in that rapid titration regimens were used to induce an early onset of regular contractions in each group, as we considered it was impossible to know that the stimulatory effect of doubling the infusion rates of prostaglandin $E_{2}$ was quantitatively equivalent to doing the same with oxytocin. It is therefore not surprising that the results were different.

By using the titration regimens an initial uterine response occurred at a comparable time with both substances, though regular contractions of similar amplitude generally occurred earlier with oxytocin. Despite this fact prostaglandin $E_{2}$ was more effective in dilating the cervix, and it is our impression that this substance had a greater stimulatory effect on the uterus than oxytocin in the dose range used. One feature tending to confirm this impression was the finding that while prostaglandin $E_{2}$ invariably resulted in spontaneous rupture of the membranes, this occurred before dilatation of the cervix had reached $6 \mathrm{~cm}$ in eight out of 15 patients. With oxytocin this was so in only two out of the nine successes. With both agents basically two types of response were elicited. One resembled normal labour in that progressive cervical dilatation occurred with time, while in the other little or no change in dilatation resulted for many hours, usually until the onset of spontaneous membrane rupture. About one-third of the successes in each group were in this latter category.

With regard to the practicality of using oxytocin to induce labour in the presence of intact membranes, we feel that a greater success rate could probably be achieved if the infusion rate were increased above that required to induce contractions which appear "optimum" on an external tocograph. In effect oxytocin titration would be against cervical dilatation rather than contractions. The limitation of such a policy is a possibility of causing uterine hypertonus, though Francis et al. (1970) did not demonstrate this in their series of 130 inductions with oxytocin infusions in doses ranging from 2 to $128 \mathrm{mU} / \mathrm{min}$. We feel, however, that there are possible dangers of pursuing a similar policy of increasing the dose of prostaglandins above that required to induce optimum contractions. Besides maternal disturbance caused by possible vomiting and soreness of the arm it is our impression that fetal distress may be provoked, for contractions of excessive frequency or strength may result or uterine hypertonus may occur, as recently reported by Roberts and Turnbull (1971).

In this study the necessity for performing fetal blood sampling to establish the significance of fetal heart variations was noticeably different in the two groups, though a $\mathrm{pH}$ of $<7.20$ was found in only one instance. It is possible that these findings could have been minimized had the infusion rates been reduced after spontaneous rupture of the membranes. This occurred at an early stage of cervical dilatation in five out of the six subjects suspected of having fetal distress. Besides the alteration in uterine activity known to follow membrane rupture, it is possible that prostaglandins have an augmented effect on the uterus itself through vaginal absorption of prostaglandins known to be present in liquor during labour (Karim and Devlin, 1967).

Since prostaglandin $\mathrm{E}_{2}$ has a profound stimulatory effect on the uterus we feel that a detailed study of the effects of different dose levels on the metabolic and biochemical status of the fetus should be evaluated before their widespread introduction into clinical obstetric practice.

We wish to thank Professor Peter Curzen for his helpful advice, the nursing staff for their co-operation, the Board of Governors of the Westminster Hospital for a research grant, and Hewlett Packard Ltd. for the loan of monitoring equipment.

\section{References}

Beazley, J. M., Dewhurst, C. J., and Gillespie, A. (1970). Fournal of Obstetrics and Gynaecology of the British Commonwealth, 77, 193.

Beazley, J. M., and Gillespie, A. (1971). Lancet, 1, 152

Embrey, M. P. (1970). British Medical fournal, 2, 256.

Francis, J. G., Turnbull, A. C., and Thomas, F. F. (1970). Fournal of Obstetrics and Gynaecology of the British Commonwealth, 77, 594.

Karim, S. M. M., and Devlin, J. (1967). Fournal of Obstetrics and Gynaecology of the British Commonwealth, 74, 230.

Karim, S. M. M., Hillier, K., Trussell, R. R., Patel, R. C., and Tamusange, S. (1970). Fournal of Obstetrics and Gynaecology of the British Commonwealth, $77,200$.

Roberts, G., and Turnbull, A. C. (1971). British Medical fournal, 1, 702.

Turnbull, A. C., and Anderson, A. B. M. (1968). Fournal of Obstetrics and Gynaecology of the British Commonwealth, 75, 24.
University of Birmingham and Queen Elizabeth Hospital, Birmingham 15

S. J. A. POWIS, F.R.C.S., Senior Surgical Registrar

A. D. BARNES, F.R.C.S., Consultant Surgeon

P. DAWSON-EDWARDS, F.R.C.s., Part-time Consultant Surgeon
Persistent urinary infection did not occur in patients without vesico-ureteric reflux. However, both those with refiux of their own and the transplant ureters had persistent infection. When reflux affected the tunnelled transplanted ureter there was no infection, but two patients without a tunnel implant had a persistent urinary infection.

\section{Introduction}

Murray and Harrison (1963) first described the use of a tunnel method of ureteric implantation in patients receiving renal transplants. Calne (1967) also advocates the use of this method, though others (Starzl et al., 1964) use more complex techniques. 
There are to date no reports of the efficacy of this method of anastomosis in preventing vesico-ureteric reflux. This survey assesses the value of tunnel implantation, and the significance of reflux is considered.

\section{Method}

The details of the 20 patients who received cadaveric renal transplants in the two-year period from October 1968 are shown in the Table. Kidneys were grafted to the contralateral side of origin, seven to the left and 13 to the right iliac vessels. At transplantation an anterior cystotomy was performed and a submucosal tunnel $2-2.5 \mathrm{~cm}$ long was fashioned to terminate as near the ipsilateral ureteric orifice as possible. The mucosa of the transplanted ureter was anastomosed to the bladder mucosa with a continuous catgut suture. A suture was also placed outside the bladder, tethering the ureteric adventitia to the wall of the bladder to maintain the obliquity of the vesico-ureteric anastomosis. In two patients distal ureteric necrosis occurred, and subsequent direct vesico-ureteric anastomosis without a tunnel was successful in controlling the urinary leak. One patient (Case 6) received a kidney with two ureters, which were implanted separately.

Micturating cystograms were performed routinely before transplantation and again 3 to 19 months after operation. A midstream specimen of urine was examined bacteriologically, and a week later the patient was catheterized by the "notouch" technique and a second specimen of urine was taken for bacteriological examination. A maximum of $500 \mathrm{ml}$ of $25 \%$ sodium diatrizoate was introduced and the presence or absence of reflux on either bladder filling or micturition was noted. One week after the micturating cystogram a further specimen of urine was examined bacteriologically. Any infection was treated with antibiotics until two consecutive specimens were sterile (Cases 14 and 17). In 13 patients intravenous pyelography was performed between 4 and 18 months after transplantation.

\section{Results}

There was evidence of intermittent urinary tract infection in three patients before transplantation (Cases 5, 10, and 20), all of whom received appropriate antibiotics. At the time of operation a bladder swab and the urine were examined bacteriologically. In no patient was there evidence of urinary infection at that time. Micturating cystography before transplantation showed reflux in five patients (Cases 3, 8, 11, 15, and 16).

The urine examined one week before the post-transplant micturating cystograms showed evidence of infection in six patients (Cases 1, 3, 6, 15, 16, and 18). These patients were treated with antibiotics determined by sensitivity in culture. Treatment resulted in two of these patients (Cases 6 and 15) having sterile urine by one week after micturating cystography, but four had a persistent infection (Cases 1, 3, 16, and 18). Of those with sterile urine at the time of catheterization two had a transient infection which responded quickly to antibiotics, and repeat cultures remained sterile (Cases 14 and 17).

Micturating cystography after transplantation showed reflux to 10 transplanted ureters, eight of which had a tunnel implant (Cases 2, 3, 5, 10, 12, 16, 17, and 19) and two of which were direct anastomoses (Cases 1 and 18). Two patients also had reflux affecting their own ureters (Cases 3 and 16). Four out of the 10 with transplant reflux had a urinary tract infection before the micturating cystogram was performed (Cases 1, 3, 16, and 18), whereas only one out of the seven without any reflux had infection (Case 6). Of the four patients with persistent urinary infection two had a direct vesico-ureteric anastomosis without a tunnel, which allowed free reflux (Cases 1 and 18), and two had reflux affecting both the transplant ureter and their own ureter (Cases 3 and 16).

Intravenous pyelography in seven patients with transplant reflux showed two to have slight dilatation of the ureter and calices. The other five had a normal upper urinary tract. In the six with competent uretero-vesical junctions intravenous pyelography showed no evidence of dilation of ureter or calices.

\section{Discussion}

Vesico-ureteric reflux has been incriminated in the aetiology of pyelonephritis (Grana et al., 1965). It seems to be of paramount importance, therefore, that the vesico-ureteric junction of a solitary functioning kidney, as after renal transplantation, should be competent. In the present series vesico-ureteric reflux occurred in 8 out of 18 patients with a tunnel implantation and in both of those without a tunnel. The side of the graft did not influence the frequency of reflux, as out of seven grafts on the right three refluxed, and out of 13 on the left seven refluxed.

Clinical Details of 20 Patients receiving Renal Transplants

\begin{tabular}{|c|c|c|c|c|c|c|c|c|c|c|}
\hline \multirow{2}{*}{\multicolumn{2}{|c|}{$\begin{array}{l}\text { Case } \\
\text { No. }\end{array}$}} & \multirow{2}{*}{ Sex } & \multirow{2}{*}{ Age } & \multirow{2}{*}{$\begin{array}{c}\text { Date of } \\
\text { Transplant }\end{array}$} & \multirow{2}{*}{$\begin{array}{l}\text { Method of Ureteric } \\
\text { Implantation }\end{array}$} & \multirow{2}{*}{$\begin{array}{l}\text { Date of } \\
\text { Cystogram }\end{array}$} & \multicolumn{2}{|c|}{ Ureteric Reflux } & \multicolumn{2}{|c|}{ Urine Bacteriology } \\
\hline & & & & & & & $\begin{array}{l}\text { Own } \\
\text { Ureter }\end{array}$ & $\begin{array}{c}\text { Transplanted } \\
\text { Ureter }\end{array}$ & $\begin{array}{c}\text { Before } \\
\text { Cystogram }\end{array}$ & $\begin{array}{c}\text { After } \\
\text { Cystogram }\end{array}$ \\
\hline 1 & . & F. & 21 & $20 / 10 / 68$ & Vesico-ureteric suture, & $15 / 4 / 69$ & - & + & Proteus, E. coli & E. Coli persistent \\
\hline $\begin{array}{l}2 \\
3 \\
4 \\
5 \\
6\end{array}$ & $\begin{array}{l}\ldots \\
\because \\
\cdots \\
\cdots\end{array}$ & $\begin{array}{l}\text { M. } \\
\text { F. } \\
\text { F. } \\
\text { M. }\end{array}$ & $\begin{array}{l}43 \\
29 \\
38 \\
28 \\
21\end{array}$ & $\begin{array}{l}17 / 1 / 69 \\
22 / 1 / 69 \\
1 / 3 / 69 \\
30 / 4 / 69 \\
13 / 5 / 69\end{array}$ & $\begin{array}{l}\text { Tuno tunnel } \\
\text { Tunnel } \\
\text { Tunnel } \\
\text { Tunnel } \\
\text { Tunnel } \\
\text { Two ureters in two } \\
\text { tunnels }\end{array}$ & $\begin{array}{l}29 / 5 / 69 \\
12 / 8 / 70 \\
30 / 5 / 69 \\
24 / 7 / 70 \\
17 / 7 / 69\end{array}$ & $\begin{array}{c}+\overline{\text { left }} \\
\overline{-} \\
-\end{array}$ & $\begin{array}{l}+ \\
\pm \\
+\end{array}$ & $\begin{array}{l}\text { N.G. } \\
\text { Str. faecalis } \\
\text { N.G. } \\
\text { N.G. } \\
\text { Klebsiella }\end{array}$ & $\begin{array}{l}\text { N.G. } \\
\text { Str. faecalis persistent } \\
\text { N.G. } \\
\text { N.G. } \\
\text { (i)Klebsiella }\end{array}$ \\
\hline $\begin{array}{l}7 \\
8\end{array}$ & $\because$ & $\begin{array}{l}\mathbf{F} \\
\mathbf{M}\end{array}$ & $\begin{array}{l}35 \\
21\end{array}$ & $\begin{array}{l}24 / 5 / 69 \\
24 / 5 / 69\end{array}$ & $\begin{array}{l}\text { Tunnel } \\
\text { Tunnel }\end{array}$ & $\begin{array}{l}17 / 9 / 69 \\
18 / 9 / 69\end{array}$ & $\stackrel{-}{+}$ & $\overline{-}$ & $\begin{array}{l}\text { N.G. } \\
\text { N.G. }\end{array}$ & $\begin{array}{l}\text { N.G. } \\
\text { N.G. }\end{array}$ \\
\hline $\begin{array}{r}9 \\
10 \\
11 \\
12 \\
13 \\
14\end{array}$ & $\begin{array}{l}\ldots \\
\cdots \\
\cdots \\
\cdots \\
\cdots\end{array}$ & $\begin{array}{l}\text { M. } \\
\text { F. } \\
\text { F. } \\
\text { F. } \\
\text { F. }\end{array}$ & $\begin{array}{l}19 \\
50 \\
31 \\
32 \\
18 \\
19\end{array}$ & $\begin{array}{l}25 / 8 / 69 \\
26 / 10 / 69 \\
26 / 10 / 69 \\
15 / 1 / 70 \\
18 / 1 / 70 \\
22 / 1 / 70\end{array}$ & $\begin{array}{l}\text { Tunnel } \\
\text { Tunnel } \\
\text { Tunnel } \\
\text { Tunnel } \\
\text { Tunnel } \\
\text { Tunnel }\end{array}$ & $\begin{array}{l}20 / 8 / 70 \\
8 / 9 / 70 \\
10 / 8 / 70 \\
5 / 8 / 70 \\
18 / 8 / 70 \\
28 / 4 / 70\end{array}$ & $\begin{array}{c}\text { (right and lett) } \\
+\overline{-} \\
+ \text { (right) } \\
= \\
=\end{array}$ & $\begin{array}{l} \pm \\
\pm \\
\pm \\
-\end{array}$ & $\begin{array}{l}\text { N.G. } \\
\text { N.G. } \\
\text { N.G. } \\
\text { N.G. } \\
\text { N.G. } \\
\text { N.G. }\end{array}$ & $\begin{array}{l}\text { N.G. } \\
\text { N.G. } \\
\text { N.G. } \\
\text { N.G. } \\
\text { N.G. } \\
\text { (i) Proteus }\end{array}$ \\
\hline 15 & . & M. & 25 & $11 / 4 / 70$ & Tunnel & $6 / 8 / 70$ & + (left) & - & Klebsiella & $\{$ (i) E. coli \\
\hline 16 & $\cdots$ & F. & 30 & $24 / 4 / 70$ & Tunnel & $11 / 8 / 70$ & $+($ left $)$ & + & Str. faecalis, proteus & Str. faecalis, proteus \\
\hline 17 & $\cdots$ & F. & 18 & $14 / 7 / 70$ & Tunnel & $1 / 2 / 71$ & - & + & N.G. & $\{$ (i) Str. faecalis \\
\hline 18 & . & M. & 43 & $3 / 10 / 70$ & Vesico-ureteric suture, & $5 / 2 / 71$ & - & + & Str. faecalis & Str. faecalis persistent \\
\hline $\begin{array}{l}19 \\
20\end{array}$ & 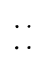 & $\stackrel{\mathrm{F}}{\mathrm{M}}$. & $\begin{array}{l}18 \\
23\end{array}$ & $\begin{array}{l}12 / 10 / 71 \\
12 / 10 / 70\end{array}$ & $\begin{array}{l}\text { Tunnel } \\
\text { Tunnel }\end{array}$ & $\begin{array}{l}15 / 1 / 71 \\
5 / 2 / 71\end{array}$ & - & \pm & $\begin{array}{l}\text { N.G. } \\
\text { N.G. }\end{array}$ & $\begin{array}{l}\text { N.G. } \\
\text { N.G. }\end{array}$ \\
\hline
\end{tabular}


There was no increased incidence of reflux in the transplanted ureter in those patients with preoperative reflux. Of the 10 with reflux four had a persistent urinary tract infection, whereas only one out of the seven without reflux had infection. Though the numbers are small it would seem that a patient without reflux of his own or the transplant ureter is least likely to suffer urinary infection. If reflux occurs in both the patient's own ureters and the transplanted ureter the risk of infection is considerable. If a tunnel has not been fashioned there is also a high risk of reflux and infection. Ureteric necrosis occurred in two patients (Cases 1 and 18). In both nearly the whole ureter was necrotic, not only the segment buried in the tunnel, and therefore the method of implantation was not incriminated. The ureteric fistulae were repaired by anastomosing infrapelvic ureter to the vault of the bladder. At the time of this second anastomosis the urine was infected in both cases, but despite protracted antibiotic therapy it remained impossible to sterilize the urine.

There does not seem to be any risk of producing serious urinary infection by catheterizing patients for a micturating cystogram, and prophylactic antibiotics are not essential, but a specimen of urine should be cultured one week after the examination. Intravenous pyelography in the seven patients with ureteric reflux showed some dilatation of the ureter and calices in two (Cases 1 and 5), though at the time of examination there was no evidence of urinary infection. Of the six with competent ureterovesical junctions there was no evidence of obstruction due to the anastomosis.

Micturating cystography is regarded as a worthwhile and safe investigation after renal transplantation, as those with infected reflux possibly need long-term antibiotics and regular bacteriological examination of the urine to reduce probable renal damage. Those with sterile reflux should also have close bacteriological control of their urine as they may be more prone to urinary infection.

\section{References}

Calne, R. Y. (1967). Renal Transplantation, 2nd Ed. London, Arnold. Grana, L., Kidd, J., Idriss, F., and Swenson, O. (1965). Fournal of Urology, 94,652 .

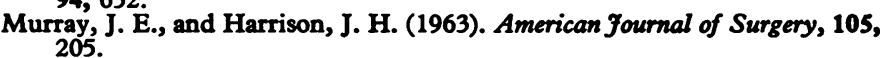

Starzl, T. E., et al. (1964). Archives of Surgery, 89, 87.

\title{
Small-intestinal Cell Turnover in Patients with Parasitic Infections
}

\author{
L. R. DA COSTA
}

British Medical fournal, 1971, 3, 281-283

\section{Summary}

Small-intestinal deoxyribonucleic acid (DNA) loss rates were measured in six patients with Strongyloides stercoralis hyperinfestation, in four patients with hookworm disease, and in eight normal controls. In the four patients with strongyloidiasis having weight loss, hypoproteinaemia, and oedema the mean DNA loss rates were $73.9,51 \cdot 6,58 \cdot 0$, and $62.2 \mathrm{ng}$ atoms DNA-P/min respectively, which was significantly higher than that of patients with hookworm disease (mean 17.3, S.D. 6.6) or in eight control subjects (mean 14.5, S.D. 7.5). In two of three patients with strongyloidiasis the high DNA loss rates fell to normal after treatment, and in two others investigated only after treatment the rates were normal. It is suggested that the high epithelial cell turnover in these patients may result in excessive loss of endogenous substances and that this may be an important mechanism in causing malnutrition and hypoproteinaemia in patients with $S$. stercoralis hyperinfestation.

\section{Introduction}

Strongyloides stercoralis has been found to be a cause of malabsorption in man (Stemmerman and Nakasone, 1960; Milner et al., 1965). In this parasitic infection the small-

\footnotetext{
Gastroenterology Laboratory and the Department of Medicine, University of the West Indies, Jamaica

L. R. DA COSTA, M.D., M.R.C.P. (Present address: Assistant Professor of Medicine, Division of Gastroenterology, Hôtel Dieu Hospital, Kingston, Ontario, Canada)
}

intestinal villi become flattened or convoluted with a dense inflammatory infiltrate in the lamina propria. Adult worms and larvae are found in the crypts. Sheehy et al. (1962) described malabsorption in patients with hookworm disease. They showed steatorrhoea, malabsorption of vitamin A and fat, a deficiency pattern on barium series, and flattening and clubbing of the intestinal villi. Salem and Truelove (1964) reported two cases of hookworm disease with steatorrhoea. Presumably in these parasitic disorders the flattening of intestinal villi represent a substantial loss of absorptive surface area which could account for most of the alterations in absorptive function. It is also possible that endogenous substances may be lost into the lumen of the gut in excessive amounts and that this may be an additional mechanism leading to malnutrition in these patients. The small-intestinal mucosa is dynamically the most active epithelial surface of the body in man, losing some 20-50 million cells per minute (Croft et al., 1968b). This cell loss can be estimated by measuring the deoxyribonucleic acid (DNA) content of the intestinal lumen. The rate of cell loss from the small intestine of patients with parasitic infestations is unknown. In this study small-intestinal DNA loss rates have been used to estimate the rate of cell loss in patients with $S$. stercoralis and hookworm infection.

\section{Patients and Methods}

Small-intestinal DNA loss rates were measured on nine occasions in six pateints with $S$. stercoralis infection. All were males, and their average age was 25 years (Table I). The following case is typical of patients with malabsorption due to $S$. stercoralis infection.

Case Report.-A 15-year-old boy presented with a three-month history of nausea, anorexia, vomiting, and weight loss. He also noted increasing diarrhoea and, one week before admission, oedema of his legs. On examination he was seen to be a thin, malnourished 